Check for updates

\section{London}

Cite this as: $B M J 2020 ; 371: m 4661$ http://dx.doi.org/10.1136/bmj.m4661 Published: 26 November 2020

\title{
Covid-19: Most of England will be in toughest two levels of restrictions after lockdown
}

\section{Shaun Griffin}

The vast majority of England will be placed under high or very high alert levels when the country's national lockdown ends on 2 December, the health secretary has announced.

The announcement by Matt Hancock, made in a statement to parliament on Thursday 26 November, followed the publication of the government's covid winter plan earlier this week, which set out the criteria for determining tiers and the levels of restrictions for each. ${ }^{1}$ Tier 1 will face the lowest level of restrictions and tier 3 the highest.

The government website, which allows searching of new tier levels by postcode, crashed almost immediately after the announcement. ${ }^{2}$

Areas with the toughest tier 3 restrictions will include Leicester and Greater Manchester-which have been under the highest levels of restrictions for some time-as well as Bristol, the West Midlands, and Kent, where Hancock said cases had recently risen sharply.

Most areas in England will enter tier 2. This includes Liverpool, which has been moved down from tier 3 after a fall in cases, London, and Hancock's own constituency in Suffolk. Although the county of Berkshire is in tier 2, the town of Slough within it will be in tier 3 .

Cornwall, the Isle of Wight, and the Isles of Scilly, which have the country's lowest covid-19 case rates, are the only areas to have been allocated to the lowest level of restrictions under tier 1.

\section{Fall in cases}

Hancock praised Liverpool for following the restrictions and "embracing community testing." He said, "In the Liverpool city region the number of cases has fallen by more than two thirds. In the borough of Liverpool itself, where mass testing took place, cases have fallen by three quarters."

However, the basis for the government's claims about the link between the fall in cases and community testing has been questioned. ${ }^{3}$ Jonathan Ashworth, Labour's shadow health secretary, highlighted the low level of testing among "poorer, harder-to-reach groups" in Liverpool and the lack of financial support for low paid workers if they have to isolate.

Hancock said, in an apparent swipe at the Manchester mayor Andy Burnham, who challenged the government on its approach last month, "Unfortunately we did see the impact on the number of cases going up and continuing to go up in those areas where local leaders were not working alongside us, and it was a sharp contrast . . . in Liverpool but also in other areas where local leadership were so constructive.”
Hancock added that the tiers would be reviewed weekly from 16 December. "When setting the boundaries ... we've looked not just at geographical areas but the human geographies which influence how the virus spreads, like travel patterns and the epidemiological situation in neighbouring areas," he said.

Commenting on the announcement, Layla McCay, director at the NHS Confederation, said, "The NHS is gearing up for an extremely busy winter with covid-19 cases still high in a number of areas, so while we support the move to regional tiers that are stronger than they were before, now is not the time for people to let down their guards.

"The mission to protect the NHS remains more important than ever. The government should not hesitate to take tougher action when the tiers are reviewed in a fortnight's time if that's what is needed.”

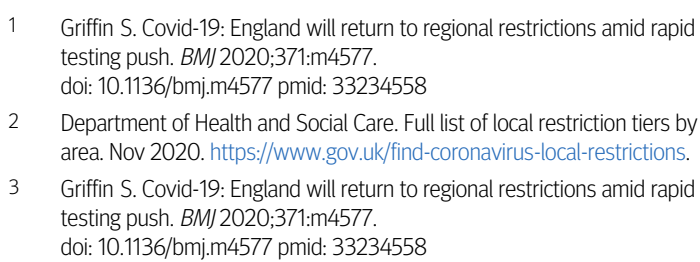

Griffin S. Covid-19: England will return to regional restrictions amid rapid testing push. BMJ2020;371:m4577. doi: 10.1136/bmj.m4577 pmid: 33234558

2 Department of Health and Social Care. Full list of local restriction tiers by area. Nov 2020. https://www.gov.uk/find-coronavirus-local-restrictions.

3 Griffin S. Covid-19: England will return to regional restrictions amid rapid testing push. BMJ 2020;371:m4577.

doi: 10.1136/bmi.m4577 pmid: 33234558

This article is made freely available for use in accordance with BMJ's website terms and conditions for the duration of the covid-19 pandemic or until otherwise determined by BMJ. You may use, download and print the article for any lawful, non-commercial purpose (including text and data mining) provided that all copyright notices and trade marks are retained. 